\title{
Mind Mapping: Teaching Students to Think Critically on Basic Chemical Law Material
}

\author{
Aisyiyah Dinnur Utami ${ }^{1}$, Eko Yuliyanto ${ }^{2 *}$, Fitria Fatichatul Hidayah ${ }^{3}$ \\ 1,2,3 Department of Chemistry Education, Universitas Muhammadiyah Semarang \\ *E-mail Corresponding Author: ekoyuliyanto@unimus.ac.id
}

\begin{abstract}
Chemistry materials with abstract and mathematical properties necessarily require the use of appropriate learning methods so that students can understand or relate concepts and explore their critical thinking skills. The aim of this study is to look at how mind mapping learning method has effects on students' critical thinking skills in basic chemical law material. It is a quasi-experimental study with a non-equivalent control group. Tests and questionnaires were used as research instruments. The variable measured was students' critical thinking. The findings reveal that mind mapping learning method has an effect on students' critical thinking skills. This can be seen from the average scores of student responses and better learning outcomes. There was an increase in critical thinking skills in the experimental class from the pre-test average score of 48.31 to the post-test average score of 51.40. Meanwhile, the control class went through a decrease from the pre-test average score of 47.95 to the post-test average score of 44.40. Students in the experimental class who were treated with mind mapping method performed better and had higher learning outcomes than students in the control class who did not receive the treatment.
\end{abstract}

Keywords: learning method; mind mapping; critical thinking

\begin{abstract}
Abstrak
Materi kimia yang memiliki karakteristik abstrak dan matematis memerlukan metode pembelajaran yang tepat sehingga siswa dapat memahami atau mengaitkan konsep-konsep dan menggali kemampuan berpikir kritis siswa. Tujuan penelitian ini adalah untuk mengetahui pengaruh metode pembelajaran peta konsep terhadap keterampilan berpikir kritis siswa pada materi hukum dasar kimia. Jenis penelitian yang digunakan adalah quasi eksperimen dengan desain nonequivalent control group. Instrumen penelitian yang digunakan adalah tes dan angket. Variabel yang diukur adalah berpikir kritis siswa. Hasil penelitian menunjukkan bahwa metode pembelajaran peta konsep berpengaruh terhadap keterampilan berpikir kritis siswa. Hal ini dapat dilihat pada nilai rata-rata respon siswa dan hasil belajar yang lebih tinggi. Pada kelas eksperimen mengalami peningkatan ketrampilan berpikir kritis dari nilai rata-rata Pretest sebesar 48,31 ke nilai rata-rata Post-test sebesar 51,40. Sedangkan pada kelas kontrol mengalami penurunan dari nilai rata-rata Pre-test sebesar 47,95 ke nilai rata-rata Post-test sebesar 44,40. Siswa kelas eksperimen yang diberi perlakuan dengan metode peta konsep mempunyai keterampilan berpikir kritis lebih tinggi dibandingkan kelas kontrol.
\end{abstract}

Kata kunci: metode pembelajaran; peta konsep; berpikir kritis 


\section{Introduction}

Basic chemical law material is one of the Chemistry subject matters which is abstract and mathematical, making it difficult for students to understand the content (Apriyanto, Mulyani \& Susanti, 2014). The chapter of basic chemical law comprises of the following topics: law of conservation of mass, law of constant proportions, law of multiple comparison, Gay Lussac law of volume comparison, Avogadro law, and basic formulas for mole concept. All of the materials on basic chemical law are interconnected, meaning that if one law concept is not well-understood, students will find it difficult with some other law concepts (Wasonowati, Redjeki \& Dwi, 2014). The basic chemical law material is important since the concepts will later be used as a foundation for going through the chemical calculation materials. Because the concepts of basic chemical law are memorization and requiring understanding, there is a need for appropriate learning methods to help students understand the material better.

Success in a learning process cannot be separated from approaches or teaching methods used by teachers in schools (Agustin, Supardi \& Supardi, 2018). Learning methods help students obtain information, ideas, skills, values, thinking skills, and selfactualization, as well as provide effective and systematic learning so that students can improve their learning abilities in terms of knowledge and skills more easily and effectively (Daryanto \& Karim, 2017). Learning methods which can increase students' active participation in learning are ones that can improve students' understanding of the subject matter (Sunarto, Sumarni \& Suci, 2011). They play an important role in achieving learning objectives, thus each learning material requires a different method based on the learning objectives. The materials in Chemistry have several characteristics, including: 1) the majority of which is abstract; 2) Chemistry is a simplification of reality; 3) the nature of Chemistry is 2 sequential and evolving rapidly; and 4) Chemistry is more than just a problem solving; but also dealing with descriptions such as chemical facts, chemical rules, chemical terms, and so forth (Kean \& Middlecamp, 1985: 9). According to this statement, each Chemistry learning material has unique characteristics, requiring the use of appropriate method in its delivery. According to Nuryanti, Zubaidah \& Diantoro (2018), the use of learning methods in schools is believed to facilitate students' critical thinking skills.

Critical thinking can be defined as the ability to think clearly and rationally, which allows students to better understand problems and find the best solutions to the problems they face (Yudiana, 2015). The $21^{\text {st }}$ century learning skills must be empowered in today's learning activities, such as critical thinking skills, problem solving, metacognition, communication skills, collaboration, and other various skills (Zubaidah, 2017). In accordance with secondary school Graduate Competency Standards (SKL) in terms of the students' skills aspects, there are cognitive and psychomotor skills, particularly regarding with being creative, productive, critical, independent, collaborative, and communicative through a scientific approach as a continuation of what has been learned in the educational unit. Improving critical thinking skills in learning requires planning so that students can make decisions carefully (Adiwijaya, Suarsini \& Lukiati, 2016). Critical thinking skill is very essential in today's learning. According to Sulistiani \& Masrukan (2016), it has long-term benefits by assisting students in managing their learning skills.

According to Rosen \& Tager (2014), the trigger to think in the teaching and learning process is the regular use of mind mapping. Mind mapping can help students think and express their thinking processes. Meaningful learning is characterized by the presence of relationships between aspects, concepts of information, or new situations and relevant components in the cognitive 
structures (Daryanto \& Karim, 2017: 67). Thus, the activity of connecting concepts through the use of mind mapping can result in a complete understanding and the concepts learned can be well understood (Ariyatun \& Octavianelis, 2020). According to some of these experts, mind mapping is one of the learning methods that can improve students' critical thinking skills.

Mind mapping is an effective instrument to visually present hierarchical generalizations and express the interconnectedness of propositions in the interconnected conceptual systems. In addition, mind mapping provides a concrete visual assist to help organize information before it is learned. The goal of organizational strategy is to help increase understanding, particularly through the use of organizing new materials (Eryanti, 2015). Mind mapping is a technique used to organize ideas and thoughts to be more clearly and logically (Pribadi \& Delfy, 2015). The use of mind mapping in learning activities allows students to process the information obtained when working on mind mapping through discussions. The more students who participate in discussion activities, the more opportunities students will have to explore information (Shinta, Supeno \& Khanafiyah, 2013). The mind mapping learning method has advantages in terms of increasing meaningful learning and conceptual understanding in students (Taie, 2014). One effort that can be made to improve the effectiveness of learning is to engage the potential minds of the students themselves in learning (Puspitayanti \& Maryam, 2014). The students' ability to create concept mapping can be used to assess students' learning outcomes, that is, a complete understanding (Maurisa \& Abdullah, 2016).

Learning with mind mapping is expected to help students understand or relate the concepts of a material being studied, as well as to uncover students' critical thinking skills in order to improve student learning outcomes in Chemistry. According to Apriyanti, Abdurrahman \& Viyanti (2014), through the mind mappingintegrated ARIAS learning method, there is a significant positive linear effect of critical thinking dispositions on student learning outcomes at MAN 1 Bandar Lampung. In practice, there are several steps to take if someone is about to create a mind mapping. It is done to ensure that the mind mapping is systematically and clearly structured. The steps in creating mind mapping are as follows: a) studying a reading text from a source book, b) determining relevant concepts, c) sorting the concepts embedded in the text hierarchically, starting from the most inclusive to specific concepts, d) arranging the sorted concepts on paper by placing the most inclusive concepts at the top, and e) connecting the concepts with conjunctions (Labibah \& Ernawati, 2017).

According to initial observation at one of Senior High Schools in Semarang, the learning process was still conducted in a teacher-centered manner, so most students struggled to find the core concepts and connected the concepts of a material in Chemistry lesson. Based on this issue, it is necessary for this study to employ a mind mapping learning method in order to improve students' critical thinking skills in Chemistry classes.

\section{Research Methodology}

The experiment type used is quasiexperimental method. This method is a type of comparison in which the effect of applying a treatment to an object is compared and the magnitude of which is determined. This study employed a non-equivalent control group design, with two classes examined for comparison, namely experimental class and control class. The following is the research design of non-equivalent control group:

Table 1

Research Design of Non-Equivalent Control Group

\begin{tabular}{ccc}
\hline $\mathrm{O}_{1}$ & $\mathrm{X}$ & $\mathrm{O}_{2}$ \\
\hline $\mathrm{O}_{3}$ & & $\mathrm{O}_{4}$ \\
\hline
\end{tabular}


(Sugiyono, 2017)

Description:

$\mathrm{O}_{1} \quad$ : Pre-test for experimental class

$\mathrm{O}_{2} \quad$ : Post-test for experimental class

$\mathrm{O}_{3} \quad$ : Pre-test for control class

$\mathrm{O}_{4} \quad$ : Post-test for control class

$\mathrm{X} \quad$ : Treatment

This study was carried out at MAN 1 Semarang in $X^{\text {th }}$ grade in the even semester of the academic year of 2019/2020. It was conducted in three meetings in April 2020.

The population of the study was $X^{\text {th }}$ Grade of Natural Science Program (MIPA) of MAN 1 Semarang. The sampling technique used was random sampling, and the sample consisted of two classes, namely X MIPA 3 with 34 students and class X MIPA 7 with 36 students.

Based on the non-equivalent control group research design, the following research procedures can be developed: (1) pre-test administered prior to treatment in experimental and control classes, (2) learning process activities using mind mapping learning method in experimental class and lecturing method in control class, and (3) post-test given after the learning process in both classes, and (4) data analysis on research findings using statistical testing.

The independent variable in this study is the use of mind mapping learning method on basic chemical law material. The use of mind mapping learning method is made the independent variable because it causes changes affecting other variables. The dependent variable in this study is students' critical thinking on basic chemical law material.

In this study, the data were collected using a critical thinking questionnaire instrument and summative tests in the form of multiple choices which were designed in accordance with critical thinking indicators. Validity and reliability tests were administered prior to the use of this research instrument. The data analysis technique used went through several stages, including: (1) analysis prerequisite test to determine whether data analysis for hypothesis testing can be continued with parametric or non- parametric methods, (2) Hypothesis testing through paired sample test, which compares data from the same subject but with different treatments. According to Widiyanto (2013), one of the testing methods used to assess the effectiveness of a treatment is paired sample $t$-test (discrimination test), which is marked as the difference in the average before (pre) and after (post) the treatments. SPSS statistical testing was used to process the data.

\section{Research Findings and Discussion}

The data obtained from this study were the students' critical thinking skills before and after the treatments of mind mapping model in Chemistry lesson on the basic chemical law material at MAN 1 Semarang. Due to the impact of the Covid-19 pandemic, meeting restrictions (social distancing) have been imposed in all departments, including teaching and learning activities in schools. Therefore, this study was conducted through online using a remote video conference application (zoom). Before conducting the study, the validity and reliability of the research instrument were tested. Based on the findings of the instrument's validity test, with the condition that $r$ count $>r$ table, the item is declared valid ( $\mathrm{r}$ table $=0.361 ; \mathrm{n}=32$ ), and the instrument is declared suitable for use if Alpha Cronbach's value $>0.60$. As a result, from the validity test results on the test instrument, 34 valid items were obtained, and the reliability test results were 0.735 , indicating that the instrument was operable.

In the initial activity of the study, a Pre-test was administered to the control and experimental classes to determine the students' initial abilities before carrying out learning activities. Pre-test activities include summative pre-test as well as assessing students' critical thinking skills. Pre-test was done online using a google form link adjusted to online learning. Following the pre-test, the next activity is the learning process in the two classes using various 
methods. In the experimental class, mind mapping, assisted with Microsoft Word and Power Point apps which can be displayed during the online learning process, was given. In the meantime, in the control class, the material was delivered using Microsoft Word and Power Point media, leaving mind mapping behind. The learning activities were carried out in both classes for three meetings, with post-test at the end of each meeting. The post-test was carried out to see if there were any differences between the two classes' learning activities before and after the treatments. The post-test included summative post-test as well as assessing students' critical thinking skills. Students did the post-test via online through Google form. The final stage of the study is data analysis.
Before analyzing the data, a sample must be selected. Due to several technical obstacles related to online learning, it appears that not all students in the initial sample participated in the learning process optimally. The selection resulted in a smaller initial sample, with the experimental class reduced from 34 to 22 students and the control class reduced from 36 to 22 students. As a result, students who attended the learning process until the end were used as research subjects. Following the data collection, the first data analysis was conducted, which is, carrying out a normality test as an analysis requirement. The results of the normality test on the research data can be seen in the following table:

Table 2

Normality Test

\begin{tabular}{|c|c|c|c|}
\hline Class & Data & Sig & Description \\
\hline \multirow[t]{4}{*}{ Experimental } & Pre-test Critical & 0.017 & Normal \\
\hline & Post-test Critical & 0.866 & Normal \\
\hline & Pre-test Test Questions & 0.001 & Abnormal \\
\hline & Post-test Test Questions & 0.007 & Abnormal \\
\hline \multirow[t]{4}{*}{ Control } & Pre-test Critical & 0,024 & Normal \\
\hline & Post-test Critical & 0.019 & Normal \\
\hline & Pre-test Test Questions & 0.030 & Normal \\
\hline & Post-test Test Questions & 0.000 & Abnormal \\
\hline
\end{tabular}

Based on the normality test results, the majority of the data are normally distributed with a significance level of $1 \%$, so the data are claimed to be normally distributed because the Asymp. Sig value is $>0,01$. However, the data taken from the normality test results of the experimental class pretest, the post-test questions for the experimental class and the control class are not normally distributed with the sig value < 0,01 . Hence, non-parametric statistics was employed in the next hypothesis testing stage on both data.
In the meantime, the results of normally distributed data were then held forward through the stages of testing the parametric statistical hypothesis. The next data analysis is homogeneity test, which seeks to validate that both classes used as research samples are homogeneous. The homogeneity test interpretation can be seen from the significant value. At a significance level of 5\%, the data is said to be homogeneous if the significant value is > 0.05 . The following are the results of the data homogeneity test:

Table 3

Homogeneity Test

\begin{tabular}{cccc}
\hline \multicolumn{5}{c}{ Homogeneity Test of Variances } \\
\hline Lavene Statistic & df1 & df2 & Sig. \\
\hline 2.355 & 1 & 42 & 0.132 \\
\hline
\end{tabular}


Based on the homogeneity test results, it can be seen that the significant value is $0.132>0.05$, implying that the two classes used as research samples are homogeneous. Following the completion of the analysis prerequisite test, the data were subjected to hypothesis testing. The research hypothesis being tested is that the use of mind mapping method can improve students' critical thinking skills and their learning outcomes in $X^{\text {th }}$ grade on basic chemical law. The hypothesis used in this study was parametric statistical test with t-test, namely Paired Sample Test. However, there was one data set using non-parametric statistical test because it did not meet the analysis prerequisites. The data aforementioned consisted of summative pre-test and posttest, so the Wilcoxon test was used to test the hypothesis. The goal of the two tests analysis is to compare the means of two groups that are related to one another. As a result, the tests compare the average scores of the pretest and post-test in one experimental class and the control class. The results of the average difference through the Paired Sample Test on the critical thinking data questionnaire can be seen in the diagram as follows:

\section{Figure 1}

Diagram of the Critical Thinking Average Scores

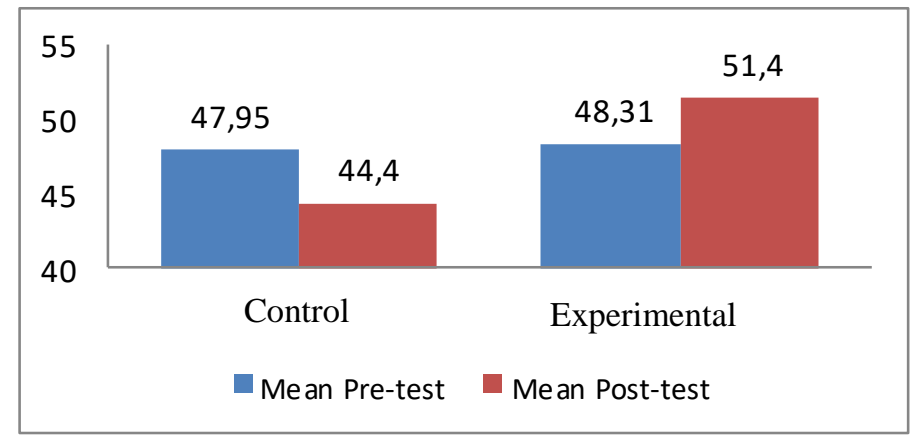

According to the test results, the posttest average scores in the experimental class are higher than its Pre-test average score. This is supported by a critically significant value of $0.000<0.05$, implying that $\mathrm{H}_{0}$ of the two variables are rejected, implying that there are significant differences in students' critical thinking abilities before and after treatment. In the control group, the average scores decreased between the pre-test and post-test. The Wilcoxon Test was then used to analyze student learning outcomes test data, as shown in the diagram below:

\section{Figure 2}

Diagram of Learning Outcomes Analysis

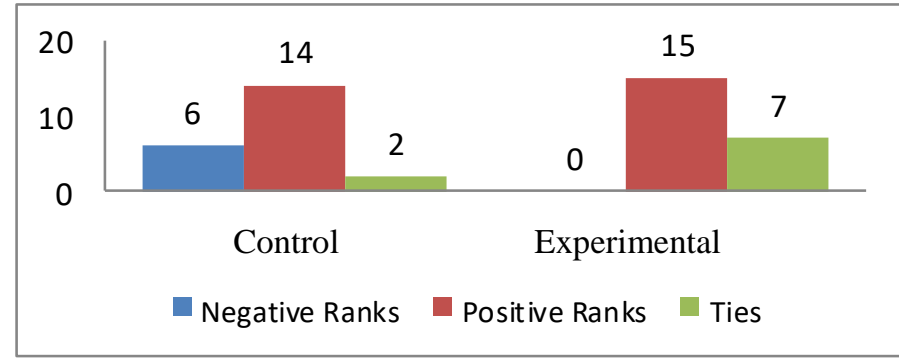


In Figure 2, there are rankings that must be taken into consideration in the Wilcoxon test outputs: those are, negative ranks which take place when the post-test is less than the pre-test, positive ranks which occur when the post-test is greater than the pre-test, and ties which happen when the post-test equals to the pre-test. Based on the Wilcoxon test results from the summative tests of the experimental and control classes, the are 15 students in positive ranks without negative ranks, and 7 students are in ties as the post-test scores equal to the pre-test scores. Meanwhile, 14 students in the control group are in positive rankings, 6 in negative rankings, and 2 in ties category.

According to the results in Figure 1, in terms of criticial thinking skills aspect, students in this study went through an increase in the average score from pre-test to post-test in the experimental class treated with mind mapping model. On the other hand, the control group had a decrease, with the average score of post-test being lower than that of pre-test. It is line with the findings by Adiwijaya, Suarsini \& Lukiati (2016), claiming that the use of mind mapping can improve students' critical thinking skills. Previous studies by Fathiyah (2019) found that the use of mind mapping learning strategy can improve activities, critical thinking skills, and student learning outcomes. The mind mapping arranged by students will assist them in carrying out thinking activities which allow them to develop the knowledge they have already had. Surely, if their information is incomplete yet, or there are things they don't understand, it will encourage them to further explore it or even ask the teacher about it. According to the findings of this study, factors encouraging students' critical thinking skills in mind mapping learning

\section{Figure 3}

The Results of Students' Mind Mapping include the arrangement of interconnected concepts that arouse the students' interest in the experimental class in the relationships embedded in the mind mapping model. The material delivery using mind mapping encourages students to analyze how they are able to comprehend the material arranged in mind mapping model. According to Negoro et al. (2018) findings, in order to generate critical thinking skills, students must have a curiosity. Another factor is that in mind mapping process, before gathering a concept, students must first read the material provided. According to Ramdiyah (2016), reviewing material to find answers as well as constructing mind mapping based on the reading material provided will trigger students to arrange a mind mapping in order to gain a meaningful relationship among the concepts. It is done in order that students can comprehend what they are reading and extend their knowledge. According to Rosyida, Zubaidah \& Mahanal (2016), reading can help students obtain more information to use as a foundation for reasoning when drawing conclusions from the concepts studied. The mind mapping arrangement activities can stimulate students' thinking by allowing them to identify important concepts, classify them, and determine the relationship between the concepts, so these activities require critical thinking skills. According to the research findings by Khoiriyah, Suratno \& Murdiyah (2015), the construction of mind mapping, also known as concept mapping, requires students' critical thinking skills, as described in the preparation steps. The results of students' mind mapping can be seen in Figure 3 as follows: 


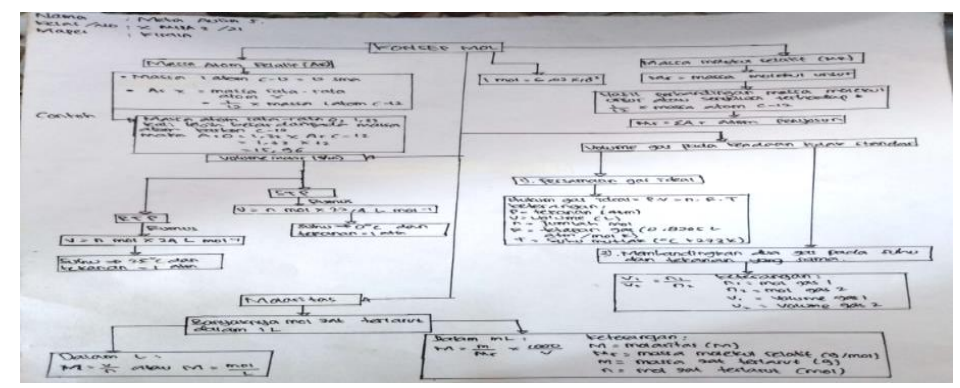

Figure 3 shows how students developed a complex and specific concept mapping, as seen from the many concepts and branches generated. Based on these findings, students had a good understanding of the material as well as analytical skills. The more concepts connected into branches are, the better the students' critical skills in identifying material into specific concepts will be. According to Labibah \& Ernawati (2017), mind mapping will guide students in seeing the meaning of a subject matter more comprehensively in each component of the concepts and recognizing the relationship between the concepts. Through mind mapping arrangement activities, students are able to memorize the relationship between concepts and the form of the concept mapping created, as well as the words used as connecting words between the concepts. The experimental class was assigned to create a concept mapping, while the control class was ordered to summarize the material in terms of points or core of the material given. However, almost all students in the control class were unable to summarize specific material or important concepts. As a result, the control class students kept working on summarizing it by copying the entire content of the Chemistry worksheet book (LKS) into their respective note books.

The measurement of students' critical thinking skills is also carried out through an assessment of evaluation carried out using multiple choice-based summative tests designed in accordance with the Critical thinking indicators referenced to Bloom's taxonomy. According to Figure 2, there are ranking differences in which the experimental class has more students with the Post-test > Pre-test scores than the control class does. The purpose of developing mind mapping in the field of 8 education is to help improve learning quality. According to Abadi, Akbar \& Fitri (2019) findings, mind mapping helps in a variety of tasks such as planning, communicating, being more creative, solving problems, focusing attention, organizing and explaining thoughts, memorizing better, learning more quickly and efficiently, and practicing to see the overall look of a material. Through mind mapping, it is easier and lightweight for students to understand material that has been particularly conceptualized using concept mapping, which in turn helps improve students' learning outcomes. Therefore, in the experimental class treated with mind mapping learning model, there was an increase in critical thinking skills based on the students' responses and summative tests and there were differences in the average scores between the experimental class and the control class.

\section{Conclusion}

Based on the findings of this study, it can be concluded that mind mapping learning method has a significant effect on students' critical thinking on basic chemical law material. This effect can be seen from the differences in the average scores of student responses on critical thinking skills, as well as from the summative tests before and after the treatment. Students in the experimental class who were treated with mind mapping method had an increase and achieved higher outputs than those in the control class who did not receive the treatment.

It is recommended that future studies can provide more extensive meetings and maximize them in order to conduct similar experimental studies to achieve more comprehensive results. 


\section{References}

Abadi, P. N., Akbar, Z. \& Fitri, S. (2019). Efektifitas Teknik Peta Pikiran untuk Meningkatkan Kemampuan Berpikir Critical Siswa. Faktor Jurnal Ilmiah Kependidikan, 6(3): 235-246.

Adiwijaya, H., Suarsini, E., \& Lukiati, B. (2016). Penerapan Pembelajaran Reciprocal Teaching Berbantuan Peta Konsep Untuk Meningkatkan Kemampuan Berpikir Critical Siswa Pada Pembelajaran Biologi. Jurnal Pendidikan: Teori, Penelitian, dan Pengembangan, 1(12): 2379-2387.

Agustin, A., Supardi K. I. \& Supardi, W. (2018). Pengaruh Penggunaan Peta Konsep Berbasis Multilevel terhadap Pemahaman Konsep Kimia SMA. Chemistry in Education, 7(2): 8-13.

Apriyanti, L, Abdurrahman \& Viyanti. (2014). Pengaruh Disposisi Berpikir Critical Terhadap Hasil Belajar Melalui Aria Terpadu Peta Konsep. Jurnal Pembelajaran Fisika Universitas Lampung, 2(4): 39-50.

Apriyanto, D., Mulyani, S. \& Susanti, E. (2014). Pengaruh Metode Pembelajaran Mind Mapping dan Kemampuan Memori Siswa Terhadap Prestasi Belajar Kimia Pada Pokok Bahasan Hukum-Hukum Dasar Kimia Pada Siswa Kelas X Semester Gasal di SMA Negeri 1 Mojolaban Tahun Pelajaran 2012/2013. Jurnal Pendidikan Kimia, 3(3): 1-10.

Ariyatun \& Octavianelis, D. F. (2020). Pengaruh Model Problem Based Learning Terintegrasi STEM terhadap Kemampuan Berpikir Critical Siswa. Journal of Educational Chemistry (JEC), 2(1): 33-39.

Daryanto \& Karim, S. (2017). Pembelajaran Abad 21. Jakarta: Gaya Media.

Eryanti, E. (2015). Pengaruh Strategi Belajar
Peta Konsep Terhadap Ketuntasan Belajar Matematika Siswa. Jurnal Pendidikan Matematika Dan Matematika, 1(2): 45-58.

Fathiyah. (2019). Implementasi Metode pembelajaran Berdasarkan Masalah dipadu dengan Strategi Belajar Peta Konsep untuk Meningkatkan Aktivitas, Kemampuan Berpikir Critical, dan Hasil Belajar Biologi Siswa. Jurnal Belantika, 2(1): 37-51.

Kean, E. \& Middlecamp, C. (1985). Panduan Belajar Kimia Dasar. Jakarta: PT. Gramedia.

Khoiriyah, Suratno, B. A. \& Murdiyah, S. (2015). Pengaruh Model Integrasi Mind Map dan Question Student Have terhadap Keterampilan Berpikir Critical dan Hasil Belajar IPA Biologi Kelas VII SMP Negeri 10 Jember. Jurnal Edukasi, 2(2): 51-57.

Labibah, R. M., \& Ernawati, T. (2017). Pengaruh Penggunaan Peta Konsep terhadap Hasil Belajar IPA ditinjau dari Kemampuan Berpikir Critical. Jurnal Ilmiah Pendidikan IPA, 4(2): 19-25.

Maurisa, A. M., \& Abdullah, H. (2016). Hubungan Kemampuan Membuat Peta Konsep dengan Hasil Belajar Siswa di Kelas XI pada Materi Pokok Sistem Eksresi Manusia. Jurnal Pelita Pendidikan, 4(2): 15-19.

Negoro, R. A., Hidayah, H., Rusilowati, A. \& Subali, B. (2018). Upaya Membangun Ketrampilan Berpikir Critical Menggunakan Peta Konsep Untuk Mereduksi Miskonsepsi Fisika. Jurnal Pendidikan (Teori dan Praktik), 3(1): 45-51.

Nuryanti, L., Zubaidah, S. \& Diantoro, M. (2018). Analisis Kemampuan Berpikir Critical Siswa SMP. Jurnal Pendidikan: Teori, Penelitian, dan Pengembangan, 3(2): 155-158. 
Puspitayanti, N. P \& Maryam, S. (2014). Peta Pikiran Dan Peta Konsep. Jurnal Pendidikan dan Pengajaran, 47(1): 1121.

Pribadi, B. A., \& Delfy, R. (2015). Implementasi Strategi Peta Konsep (Concept Mapping) dalam Program Tutorial Teknik Penulisan Artikel Ilmiah Bagi Guru. Jurnal Pendidikan Terbuka Dan Jarak Jauh, 16(2): 76-88.

Ramdiyah, S. (2016). Potensi Tahapan Strategi PQ4R dikombinasikan Peta Konsep Pada Pembelajaran Biologi untuk Meningkatkan Keterampilan Metakognitif dan Berpikir Critical Siswa. Jurnal Edukasi Matematika dan Sains, 3(1): 33-44.

Rosen, Y., \& Tager, M. (2014). Making Student Thinking Visible Through a Concept Map in Computer-Based Assessment of Critical Thinking. Journal of Educational Computing Research, 50(2): 249-270.

Rosyida, F., Zubaidah, S. \& Mahanal, S. (2016). Memberdayakan Keterampilan Berpikir Critical dengan Metode pembelajaran Remap TmPS (Reading Concept Map Timed Pair Share). Seminar Nasional XIII Pendidikan Biologi FKIP UNS, 13(1): 209-214.

Shinta N, G., Supeno, E. S. \& Khanafiyah, S. (2013). Penerapan Peta Konsep dalam Pembelajaran untuk Meningkatkan Hasil Belajar Fisika pada Pokok Bahasan Gerak Lurus Siswa Kelas VII SMP. Unnes Phsysic Eduation Journal, 2(1): 7-14.

Sugiyono. (2017). Metode Penelitian Kuantitatif, Kualitatif, dan R\&D. Alfabeta CV. Bandung

Sulistiani, E, \& Masrukan. (2016). Pentingnya Berpikir Critical dalam Pembelajaran Matematika untuk Menghadapi MEA.
Prosiding Seminar Nasional Matematika, 1(1): 605-612.

Sunarto, W., Sumarni, W. \& Suci, E. (2011). Hasil Belajar Kimia Siswa Dengan Metode pembelajaran Metode ThinkPair-Share Dan Metode Ekspositori. Jurnal Inovasi Pendidikan Kimia, 2(1): 244-249.

Taie, E. S. (2014). Concept Mapping as an Innovative Teaching Strategy to Enhance Cognitive Learning in Nursing Administration Course. International Journal for Innovation Education and Research, 2(7): 11-25.

Wasonowati, T., Redjeki, R. R. \& Dwi, R. (2014). Penerapan Model Problem Based Learning (PBL) Pada Pembelajaran Hukum-Hukum Dasar Kimis ditinjau dari Aktivitas dan Hasil Belajar Siswa Kelas X IPA SMA Negeri 2 Surakarta Tahun Pelajaran 2013/2014. Jurnal Pendidikan Kimia (JPK), 3(3): 6675 .

Widiyanto, A. M. (2013). Statistika Terapan: Konsep dan Aplikasi dalam Penelitian Bidang Pendidikan, Psikologi dan Ilmu Sosial Lainnya. Jakarta: PT. Elex Media Komputindo.

Yudiana, N. I. (2015). Peningkatan Kemampuan Berpikir Critical Melalui Penerapan Metode pembelajaran Deep Dialog Critical Thinking dalam Pembelajaran Ekonomi Pada Siswa SMK N 1 Yogyakarta. Skripsi. Universitas Negeri Yogyakarta. Yogyakarta.

Zubaidah, S. (2017). Keterampilan Abad Ke21: Keterampilan Yang Diajarkan Melalui Pembelajaran. Seminar Nasional Pendidikan dengan Tema "Isu-Isu Strategis Pembelajaran MIPA Abad 21. Program Studi Pendidikan biologi STKIP Persada Khatulistiwa Sintang. Kalimantan Barat 10 Desember 2016. 
Mind Mapping: Teaching ...

Copyright ( $~ 2021$ JEC | ISSN 2715-3029 (p) 2685-4880 (e) Volume 3, Issue 1, 2021 